\title{
MACROZOOBENTHOS OF LAKES OF UZBEKISTAN
}

Matmuratov Muratbay Allamuratovich teacher

Karakalpak State University, Nukus, Uzbekistan

Saparov Abdurahman Danabaevich candidate of biological sciences, dean

Nukus State Pedagogical Institute,

Nukus, Uzbekistan

Ismoilov Khojiakbar Faizievich

assistant

Tashkent State Agrarian University,

Tashkent, Uzbekistan

Beisheeva Shahnoza Azadovna

teacher

Secondary school No. 71,

Tashkent, Uzbekistan

Mirzambetov Nurlibay

trainee

Karakalpak Research Institute of Natural Sciences,

Nukus, Uzbekistan

\section{ДОННАЯ ФАУНА НЕКОТОРЫХ ОЗЕР УЗБЕКИСТАНА}

Матмуратов Муратбай Алламуратович преподаватель

Каракалпакский государственный университет,

2. Нукус, Узбекистан

Сапаров Абдурахман Данабаевич

кандидат биологических наук, декан факультета

Нукусский государственный педагогичекий университет,

2. Нукус, Узбекистан

Исмоилов Ходжиакбар Файзиевич

ассистент

Ташкентский государственный аграрный университет,

2. Ташкент, Узбекистан

Бейшеева Шахноза Азадовна

преподаватель

Общеобразовательная средняя школа № 71,

2. Ташкент, Узбекистан

Мирзамбетов Нурлыбай

стажер

Каракалпакский научно-иследовательский институт естественных наук,

Нукус, Узбекистан

\section{Abstract}

DOI: $10.31618 /$ nas.2413-5291.2020.3.58.279

Species composition of macrozoobenthos of 6 lakes from different regions (north, center, south) of the republic have been studied. Total 111 species of bottom animals have been recorded. List of dominant species is presented. Using coefficient of Sörensen-Czekanowski similarity of species composition of macrozoobenthos of the lakes studied have been determined.

\section{Резюме}

Изучен качественный состав макрозообентоса 6 озер из разных регионов (север, центр, юг) республики. Всего отмечен 111 вид донных животных. Приведен список доминирующих видов. При помощи коэффициента Сёренсена-Чекановского определено сходство качественного состава макрозообентоса исследованных озер.

Keywords: macrozoobenthos, lakes, species composition, fauna similarity, Uzbekistan.

Ключевые слова: макрозообентос, озера, видовой состав, сходство фаун, Узбекистан.

\section{Introduction}

The biological productivity of water bodies is determined by the vital activity of hydrobionts, one of the most important link of which in aquatic ecosystem of water bodies is the aquatic bottom fauna (zoobenthos). Benthic animals enter into various, primarily trophic, connections with organisms of practically all ecotopes of water bodies. The most 
important role of macrozoobenthos organisms play as elements of the fish food. Such important commercial fish species as the carp, crucian carp, bream, roach, black amur, and also such Red Data Book species as barbell, showel-noses, white-eye bream feed largely on aquatic benthic fauna [5]. In the waterbodies of Uzbekistan and throughout Central Asia, the bottom fauna makes up the bulk of the forage base of most commercial fish species.

In Uzbekistan the macrozoobenthos of lakes was studied by A.M. Mukhamediev [6], S. Embergenov [2, etc.], B. Bekmurzaev [1, etc.] and other. However, most of these works date back to the 1960-1970s. Also, there are practically no generalizing and comparative works.

\section{Material and methods}

The material is collected seasonally (spring, summer, autumn) during 2000-2018 using Petersen's dredging and is processed according to conventional methods [9-12]. Identification of hydrobionts led by modern guides $[7,8,13$, etc. $]$.
To assess the similarities and differences in the species composition of the macrozoobenthos of lakes, the Sörensen-Czekanowski formula was used:

$$
\mathrm{K}=2 \mathrm{C} \times 100 \%
$$

where $\mathrm{A}$ and $\mathrm{B}$ are number of species in two compared lakes, $\mathrm{C}$ is the number of species common to this pair, $\mathrm{K}$ is the coefficient of similarity of the species composition.

Seven lakes from different (south, north, west, east, center) regions of the republic were studied: Sarykamysh (Karakalpakstan), Western Karateren (Wetland Sudochie, Karakalpakstan), Ullishorkul (Khorezm viloyat $=$ province), Karakir (Bukhara viloyat), Tuzkan (Jizzakh viloyat), Sarykamysh (Fergana viloyat) (fig. 1).

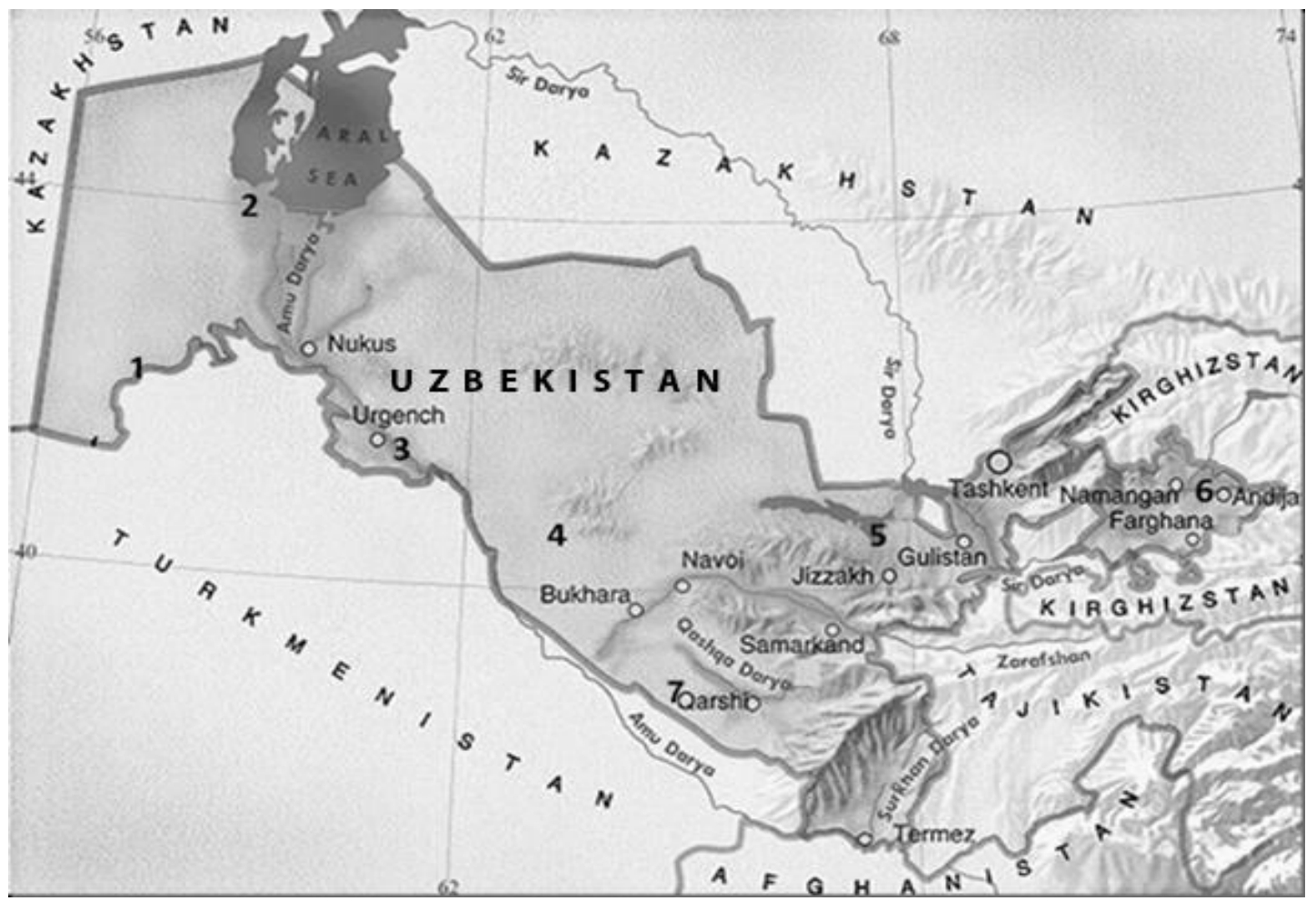

Fig. 1. Location of the lakes studied. 1: Sarykamysh, 2: Western Karateren, 3: Ullishorkul, 4: Karakir, 5: Tuzkan, 6: Sarykamysh, 7: Sichankul

Results and discussion

As can be seen from the table 1, the studied lakes of different areas, depths, water salinity, with different soils. The only freshwater lake is Sarykamysh in the Fergana Valley. The rest of the lakes are brackish.

Main abiotic parameters of the studied lakes

\begin{tabular}{|c|c|c|c|c|c|}
\hline Lakes & $\begin{array}{c}\text { Area, } \\
10^{3} \\
\text { ha }\end{array}$ & $\begin{array}{c}\text { Maximal depths, } \\
\mathrm{m}\end{array}$ & $\begin{array}{c}\text { Dominant depths, } \\
\mathrm{m}\end{array}$ & $\begin{array}{c}\text { Salinity, } \\
\mathrm{g} / \mathrm{l}\end{array}$ & Soils \\
\hline $\begin{array}{c}\text { Sarykamysh } \\
\text { (Karakalpakstan) }\end{array}$ & 387.5 & 40.0 & $5.0-7.0$ & $11.0-13.0$ & silt and sand \\
\hline West Karateren & 0.4 & 1.7 & $0.8-1.2$ & $4.0-6.0$ & gray silt \\
\hline Tuzkan & 700.0 & 20.0 & 12.0 & 10.0 & gray silt \\
\hline $\begin{array}{c}\text { Sarykamysh (Fergana } \\
\text { viloyat) }\end{array}$ & 26.2 & 7.0 & 3.0 & 0.8 & $\begin{array}{c}\text { gray and black } \\
\text { silts }\end{array}$ \\
\hline
\end{tabular}




\begin{tabular}{|c|c|c|c|c|c|}
\hline Ullishorkul & 1.8 & 4.5 & 1.5 & 5.8 & gray silt \\
\hline Karakir & 26.2 & 5.0 & $1.5-2.0$ & 10.7 & sand \\
\hline Sichankul & 7.5 & 20.0 & 9.0 & 7.0 & sand \\
\hline
\end{tabular}

A total of 187 species of bottom animals were observed, the most diverse was the benthos of freshwater lake Sarykamysh (Fergana viloyat), the least - in brackish lakes (tables 2, 3). As in most of lakes in Central Asia, chironomids were most diverse (86 species $=$ almost half of all species of macrozoobenthos) (table 3). Other groups are represented by a much smaller number of species: Odonata - 15 species, Coleoptera - 7, Diptera (excluding chironomids) - 10, Molluska - 12, Annellida - 10, Ephemeroptera - 11. The rest of the groups of organisms are represented by single species.

Dominant species of macrozoobenthos of studied lakes (SKK - Sarykamysh, Karakalpakstan), KT - West

Karateren, TZ - Tuzkan, SKF - Sarykamish (Fergana Valley),

US - Ullishorkul, KK - Karakir, SI - Sichankul)

\begin{tabular}{|c|c|c|c|c|c|c|c|}
\hline Taxa / Lakes & SKK & KT & $\mathrm{TZ}$ & SKF & US & KK & SI \\
\hline \multicolumn{8}{|c|}{ ANNELIDA } \\
\hline Paranais simplex Hrabe & + & + & + & - & - & + & + \\
\hline P. littoralis O.F. Müller & + & - & + & - & - & + & + \\
\hline Tubifex sp. & - & + & - & + & + & - & - \\
\hline Nereis diversicolor O.F. Müller & + & + & - & - & - & - & - \\
\hline \multicolumn{8}{|c|}{ MOLLUSCA } \\
\hline Colletopterum cyreum (Kobelt) & - & - & - & + & - & - & - \\
\hline Corbicula fluminalis O.F.Müller & - & - & - & + & - & - & - \\
\hline Physella acuta Drapamaud & - & + & + & + & - & - & + \\
\hline Cerastoderma isthmicum Issel & + & - & - & - & - & - & - \\
\hline Lymnaea truncatula O.F. Müller & - & + & + & + & - & - & - \\
\hline $\begin{array}{c}\text { Caspiohydrobia conica Logvin. } \\
\text { et Starobog. }\end{array}$ & - & + & - & - & - & - & - \\
\hline \multicolumn{8}{|c|}{ CRUSTACEA } \\
\hline $\begin{array}{l}\text { Macrobrachium nipponense De } \\
\text { Haan }\end{array}$ & + & + & + & + & + & + & + \\
\hline $\begin{array}{c}\text { Turkogammarus aralensis } \\
\text { (Uljanin) }\end{array}$ & + & + & - & - & - & - & - \\
\hline $\begin{array}{l}\text { Mesomysis kowalevskii } \\
\text { Czerniavsky }\end{array}$ & - & - & + & + & + & - & + \\
\hline $\begin{array}{l}\text { Paramysis lacustris } \\
\text { (Czerniavsky) }\end{array}$ & + & + & - & + & + & - & + \\
\hline \multicolumn{8}{|c|}{ INSECTA } \\
\hline Anax imperator Leach & - & - & - & - & - & + & + \\
\hline Cloen dipterum $\mathrm{L}$. & - & - & + & + & + & + & - \\
\hline Caenis macrura Stephens & - & + & + & + & + & - & - \\
\hline Ecnomus tenellus Rambur & - & - & + & + & - & - & - \\
\hline Chyronomus salinarius Kieffer & + & + & + & - & + & + & + \\
\hline Ch. Halophilus Kieffer & + & + & - & - & - & + & + \\
\hline Ch. thummi Kieffer & + & + & + & + & + & + & - \\
\hline Cricotopus tenellus Fabricius & - & - & - & + & - & - & - \\
\hline C. silvestris (Fabricius) & - & + & + & + & + & + & + \\
\hline Procladius ferrugineus Kieffer & + & + & + & + & + & + & - \\
\hline Polypedilum aberrans Tschern. & + & + & - & + & + & - & + \\
\hline $\begin{array}{l}\text { Endochyronomus tendens } \\
\text { (Fabricius) }\end{array}$ & + & - & - & + & + & - & - \\
\hline $\begin{array}{l}\text { Glyptotendipes barbipes } \\
\text { (Staeger) }\end{array}$ & - & - & - & + & - & - & - \\
\hline G. glaucus (Meigen) & - & - & - & + & - & - & - \\
\hline Total number of species & 33 & 30 & 25 & 75 & 28 & 28 & 31 \\
\hline Lakes & SKK & KT & $\mathrm{TZ}$ & SKF & US & KK & SI \\
\hline
\end{tabular}

The remains of the Aral Sea aquatic fauna have been preserved in the lakes of Sarykamysh (Karakalpakstan) and Western Karateren: polychaete Nereis diversicolor, mollusks Cerastoderma isthmicum, Caspiohydrobia cf. conica, Theodoxus pallasi, amphipod Turkogammarus aralensis (included in the Red Data Book of the Republic of Uzbekistan [3]). 
Table 3.

Taxonomic diversity (number of species) of macrozoobenthos of the lakes studied (legend as in table 2)

\begin{tabular}{|c|c|c|c|c|c|c|c|c|}
\hline Taxa /Lakes & SKK & KT & TZ & SKF & US & KK & SI & $\begin{array}{c}\text { Number of } \\
\text { species } / \%\end{array}$ \\
\hline Annelida & 5 & 4 & 3 & 6 & 4 & 4 & 5 & $10 / 5.3$ \\
\hline Mollusca & 3 & 1 & 1 & 7 & 1 & 1 & 1 & $12 / 6.4$ \\
\hline Crustacea & 2 & 1 & 1 & 1 & 1 & 1 & 3 & $5 / 2.7$ \\
\hline Chironomidae & 20 & 19 & 17 & 49 & 18 & 18 & 19 & $86 / 46.0$ \\
\hline Other Diptera & 5 & 5 & 4 & 5 & 9 & 5 & 5 & $15 / 8.0$ \\
\hline Odonata & 4 & 3 & 2 & 8 & 3 & 3 & 4 & $15 / 8.0$ \\
\hline Coleoptera & 1 & 2 & 2 & 3 & 1 & 1 & 2 & $7 / 3.7$ \\
\hline Ephemeroptera & 2 & 2 & 2 & 7 & 3 & 2 & 3 & $11 / 5.9$ \\
\hline Trichoptera & 1 & 2 & 1 & 4 & 2 & 1 & 2 & $6 / 3.2$ \\
\hline Hemiptera & 3 & 2 & 3 & 5 & 2 & 2 & 2 & $9 / 4.8$ \\
\hline Plecoptera & 2 & 2 & 2 & 4 & 3 & 3 & 2 & $7 / 3.7$ \\
\hline Hydracarina & 1 & 1 & 1 & 2 & 2 & 1 & 1 & $4 / 2.1$ \\
\hline Total species & 49 & 44 & 39 & 101 & 49 & 42 & 49 & 187 \\
\hline
\end{tabular}

Comparison of the species composition of zoobenthos in the studied lakes revealed that the species composition of brackish water lakes is the most similar. The species composition of the

macrozoobenthos of the freshwater lake Sarykamysh of the Fergana Valley is sharply different from the species composition of the brackish lakes studied (table 4) and more similar to the bottom fauna of reservoirs [4].

Table 4.

The similarity of the species composition of macrozoobenthos of the lakes studied according to the Sörensen-Czekanowski coefficient (legend as in table 2)

\begin{tabular}{|l|c|c|c|c|c|c|c|}
\hline Lakes & SKK & KT & TZ & KK & US & SKF & SI \\
\hline Sarykamysh (Karakalakstan) & & 80 & 75 & 69 & 77 & 20 & 77 \\
\hline Western Karateren & 80 & & 68 & 70 & 78 & 21 & 66 \\
\hline Tuzkan & 75 & 68 & & 75 & 71 & 18 & 70 \\
\hline Karakir & 81 & 70 & 75 & & 68 & 19 & 67 \\
\hline Ullishorkul & 77 & 78 & 71 & 68 & & 22 & 56 \\
\hline Sarykamysh (Fergana) & 20 & 21 & 18 & 19 & 22 & & 23 \\
\hline Sichankul & 77 & 66 & 70 & 67 & 56 & 23 & \\
\hline
\end{tabular}

As practical recommendations, it is possible to propose the introduction of some invertebrates of the Aral Sea fauna such as Nereis diversicolor, Turkogammarus aralensis, Theodoxus pallasi, and Cerastoderma isthmicum into the brackish-water lakes Ullishorkul, Karakir, Tuzkan, Sichankul, and other brackish waterbodies of the republic.

\section{Acknowledgements}

The authors are grateful to O.D. Gerasimova for help in identifying of some species and to I.M. Mirabdullayev for valuable comments and editing the manuscript.

\section{References}

1. Bekmurzaev B. Bentos Karazharskoi sistemy ozer delty Amudari [Benthos of the Karazhar Lake System in Amudarya river delta] // Uzbek biol. Zhurn. 1969. 2 (in Russian).

2. Embergenov S., Khusainva N.Z. O zoobentose ozera Vostochnyi Karateren (delta Amudarii) [On the zoobenthos of lake Eastern Karateren (Amudarya river delta)] // Vestnik Karakalpak. Filiala AN UzSSR. 1970. № 2 (in Russian).

3. Krasnaya Kniga Respubliki Uzbekistan [The Red Data Book of the Republic of Uzbekistan]. Tashkent: Chinor ENK, 2019. V. 2. (in Russian).
4. Matmuratov M.A., Abdinazarov H.Kh., Sabirov Zh.Zh. et al. Makrozoobentos nekotorykh ravninnykh vodokhranilishch Uzbekistana [Macrozoobenthos of some flat reservoirs of Uzbekistan] // Vestnik Karakalpak. Otdel. Akad. Nauk Resp. Uzb. 2016. № 3. (in Russian).

5. Mirabdullayev I.M., Mirzaev U.T., Kuzmetov A.R., Kimsanov Z.O. Uzbekistan va kushni hududlar baliklar aniklagichi [Guide to fish of Uzbekistan and adjacent territories]. - Tashkent: Sano-Standart, 2011. (in Uzbek).

6. Mukhamediev A.M. Gidrobiologia vodoemov Ferganskoi doliny [Hydrobiology of waterbodies of the Fergana Valley]. - Tashkent: Fan, 1967. - (in Russian).

7. Opredelitel zooplanktona i zoobentosa presnych vod Evropeiskoi Rossii [Key to zooplankton and zoobenthos freshwaters of European Russia]. V. 2. Zoobenthos. - M. - SPb.: Tovar. nauch. izdat. KMK, 2016. (in Russian).

8. Opredelitel presnovodnykh bespozvonochnykh Rossii i sopredelnykh territoriy [Key to freshwater invertebrates of Russia and adjacent lands]. - SPb.: Zool Inst. RAS, 1994-2004. V. 1-6. (in Russian).

9. Plotnikov G.K., Peskova T.E., Shkute A., Pupinya A., Pupinsh M. Sbornik klassicheskikh metodov gidrobiologicheskikh issledovaniy dlya ispolzovanii $\mathrm{v}$ akvakulture [Collection of classic 
methods in hydrobiological researches for using in aquaculture]. - Daugavpils: Saule, 2017. (in Russian).

10. Popchenko V.I., Bulgakov G.P. Monitoring makrozoobentosa [Monitoring of macrozoobenthos] // In: Rukovodstvo po gidrobiologicheskomu monitoringu presnovodnykh ekosistem. $\mathrm{SPb}$.: Gidrometeoizdat, 1992. (in Russian).

11. Prakticheskaya gidrobiologiya. Presnovodnye ekosistemy [Pratical hydrobiology. Freshwater ecosystems] (Eds. V.D. Fedorov, V.I. Kapkov). - M.: Izd. MSU, 2006. (in Russian).

12. Salazkin A.A., Alimov A.F., Finogenova N.P. Metodicheskie rekomendatsii po sboru i obrabotke materialov pri gidrobiologicheskikh issledovaniyakh na presnovodnykh vodoyemakh: zoobentos i ego produktsiya [Methodical recommendations for collecting and processing of materials under hydrobiological researches on freshwater waterbodies: zoobenthos and its production]. - Leningrad: GosNIORKh, 1984. (in Russian). 13. Gloer
R, Meier-Brook
C. Süsswassermollusken. Ein Bestimmungschlüssel fur die Bundesrepublik Deutschland. - Hamburg: Deutsch. Jugendbund Naturbeobacht., 2003. 